Boise State University

ScholarWorks

Intermountain Bird Observatory Publications and

Presentations

Idaho Bird Observatory

$12-1-2017$

Repeated Observations of Northern Goshawks Foraging as Terrestrial Predators

Robert A. Miller

Boise State University 


\title{
LETTERS
}

J. Raptor Res. 51(4):480-482

(C) 2017 The Raptor Research Foundation, Inc.

\section{Repeated Observations of Northern Goshawks Foraging as Terrestrial Predators}

\author{
Robert A. Miller ${ }^{1}$ \\ Intermountain Bird Observatory, Boise State University, 1910 University Drive, MS1515, Boise, ID 83725 U.S.A.
}

KeY WORDS: Northern Goshawk; Accipiter gentilis; behavior; diet; foraging; ground squirrels; local adaptation; prey.

The Northern Goshawk (Accipiter gentilis; hereafter goshawk) is a generalist predator occupying boreal and temperate forests of the Holarctic (Squires and Reynolds 1997). The diet of goshawks has been studied in many areas and varies substantially among study sites, but some avian and mammalian genera are consistently represented (Squires and Reynolds 1997, Squires and Kennedy 2006). Within the northern Great Basin of North America, the breeding-season diet of goshawks is often dominated by Belding's ground squirrels (Urocitellus beldingi, also known as Spermophilus beldingi; Younk and Bechard 1994, Miller et al. 2014). The local reliance upon an open-country prey species such as the Belding's ground squirrel is higher than in other locations where goshawk diet has been studied (see summary in Miller et al. 2014). This difference may be the result of, or may foster or necessitate variation in local foraging behavior.

Goshawks have been described as sit-and-wait predators (i.e., ambush) and saltatory predators (i.e., searching while perched; Bloxton 2002, Squires and Kennedy 2006). Goshawks most often hunt from perches, but occasionally attack while on the wing (Kenward 1982). Goshawks also hunt by flying rapidly along forest edges (Johnsgard 1990, Backstrom 1991), and appear to modify their hunting styles based on vegetation characteristics (Bloxton 2002).

Some raptor species are well known for their terrestrial foraging and stalking behavior (e.g., species within the genus Caracara; Sazima 2007). Stalking prey on the ground may be more prevalent among open-country species such as Ferruginous Hawks (Buteo regalis; Wakeley 1978) or Harris's Hawks (Parabuteo unicinctus; Bednarz 1988), yet some open-country species still appear to favor hunting from perches (e.g., Red-tailed Hawks [Buteo jamaicensis]; Janes 1984). Cooper's Hawks (Accipiter cooperii), closely related to the goshawk and generally more easily observed, are known to occasionally pursue prey on foot (Curtis et al. 2006). Only one published reference provides a detailed

${ }^{1}$ Email address: RobertMiller7@boisestate.edu description of a goshawk initiating pursuit of prey on the ground as a terrestrial predator (Bergstrom 1985). However, Kenward (2006) cautions that reported observations of goshawk foraging behavior may be biased toward the most visible techniques, with other behaviors going underreported. Here, I report repeated observations of goshawks hunting Belding's ground squirrels from the ground, stalking prey in a manner similar to that of mammalian terrestrial predators.

During the first week of June 2013, I was performing goshawk surveys within the Sublett Mountains of southern Idaho $\left(42.2^{\circ}-42.5^{\circ} \mathrm{N}, 112.9^{\circ}-113.1^{\circ} \mathrm{W}\right)$. Each evening, I observed an adult goshawk hunting the sagebrush-covered (Artemisia spp.) hillside in front of my camp (Fig. 1). I observed both successful and unsuccessful attacks on Belding's ground squirrels launched from a perch approximately $100 \mathrm{~m}$ from the site. On two occasions during the week, I observed a goshawk hunting from the ground. In each instance, the goshawk flew from the forest to one end of the sagebrush-covered hillside, and perched there on the ground. After several minutes, the goshawk lowered its head and started stalking through the sagebrush, weaving around bushes across the hillside. On both occasions, the hunt was successful and the goshawk flew back into the forest with a ground squirrel. I observed similar behavior in each subsequent year, 2014, 2015, and 2016, although I do not know if the goshawk was the same individual. I have not quantified the success of this strategy, but have observed both successful and unsuccessful hunting attempts. Some attempts were unsuccessful because of disturbance. On at least two occasions, vehicle traffic on a busy road that crosses the hillside disrupted the hunting, and on one occasion a Red-tailed Hawk flushed the goshawk and chased it back into the forest.

During the 2011 and 2012 breeding seasons, prior to my reported observations, I was performing goshawk prey surveys in the Cassia Mountains, known locally as the South Hills, to the west $\left(42.0^{\circ}-42.3^{\circ} \mathrm{N}, 114.0^{\circ}-114.4^{\circ} \mathrm{W}\right.$; Miller et al. 2014). On at least three occasions, I unexpectedly flushed an adult goshawk from the ground in a nonforested landscape. Each instance occurred within a landscape dominated by sagebrush and complementary shrubs, at a distance $>100 \mathrm{~m}$ from forest. Although I did 


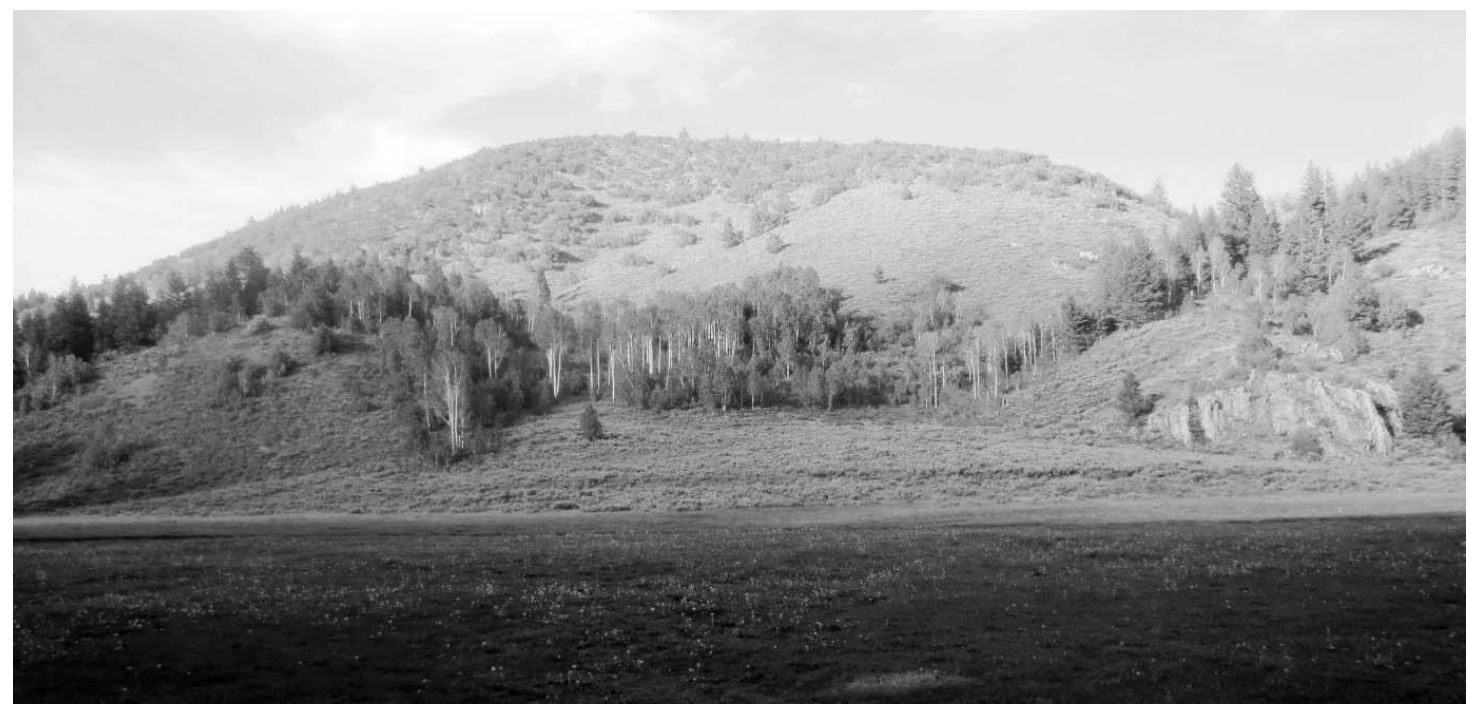

Figure 1. Study area where Northern Goshawk (Accipiter gentilis) was observed hunting as a terrestrial predator. Hunting site is the lower sagebrush-covered hillside in front of the aspen (Populus tremuloides) forest. One or more goshawks were observed launching attacks toward this hillside from a perch located (approximately $100 \mathrm{~m}$ away) behind the photographer and as a terrestrial predator.

not realize it at the time, it is possible that these observations also represented cases of terrestrial hunting.

The local dependence of goshawks upon Belding's ground squirrels (Younk and Bechard 1994, Miller et al. 2014) may have fostered a local variation in hunting style as Bloxton (2002) suggested. The terrestrial hunting approach may be more effective for capturing ground squirrels or the combination of aerial and terrestrial approaches may increase hunting success, resulting in local variation in hunting strategies.

\section{ACKNOWLEDGMENTS}

I thank the U.S.D.A. Forest Service Minidoka Ranger District for their financial, consulting, and equipment support for the completion of this project. I also thank Boise State University Raptor Research Center, the Intermountain Bird Observatory, and the many volunteers who have supported this work over the past few years.

\section{Literature Cited}

Backstrom, P. 1991. Northern Goshawk predation on Sharp-tailed Grouse. Loon 63:74-74.

Bednarz, J.C. 1988. Cooperative hunting in Harris' Hawks (Parabuteo unicinctus). Science 239:1525-1527.

Bergstrom, B.J. 1985. Unusual prey-stalking behavior by a goshawk. Journal of Field Ornithology 56: 415-415.

Bloxton, T.D., JR. 2002. Prey abundance, space use, demography, and foraging habitat of Northern Goshawks in western Washington. M.S. thesis, University of Washington, Seattle, WA U.S.A.
Curtis, O.E., R.N. Rosenfield, And J. Bielefeldt. 2006. Cooper's Hawk (Accipiter cooperii). In P.G. Rodewald [ED.], The birds of North America. Cornell Lab of Ornithology, Ithaca, NY U.S.A. https://birdsna.org/ Species-Account/bna/species/coohaw (last accessed 15 July 2017).

JANES, S.W. 1984. Influences of territory composition and interspecific competition on Red-tailed Hawk reproductive success. Ecology 65:862-870.

JoHnSGARD, P.A. 1990. Hawks, eagles, and falcons of North America. Smithsonian Institution Press, Washington, DC U.S.A.

Kenward, R. 2006. The goshawk. T. and A.D. Poyser, London, U.K.

KENWARD, R.E. 1982. Goshawk hunting behaviour, and range size as a function of food and habitat availability. Journal of Animal Ecology 51:69-80.

Miller, R.A., J.D. CARLisle, AND M.J. BECHARD. 2014. Effects of prey abundance on breeding season diet of Northern Goshawks (Accipiter gentilis) within an unusual prey landscape. Journal of Raptor Research 48:1-12.

SAzIMA, I. 2007. The jack-of-all-trades raptor: versatile foraging and wide trophic role of the Southern Caracara (Caracara plancus) in Brazil, with comments on feeding habits of the Caracarini. Brazilian Journal of Ornithology 15:592-597.

SQuiRes, J.R. AND P.L. KenNedy. 2006. Northern Goshawk ecology: an assessment of current knowledge and information needs for conservation and management. Studies in Avian Biology 31:8-62. 
AND R.T. REYNOLDS. 1997. Northern Goshawk (Accipiter gentilis). In P.G. Rodewald [ED.], The birds of North America. Cornell Lab of Ornithology, Ithaca, NY U.S.A. https://birdsna.org/Species-Account/bna/ species/norgos (last accessed 15 July 2017).

WAKELEY, J.S. 1978. Factors affecting the use of hunting sites by Ferruginous Hawks. Condor 80:316-326.
Younk, J.V. AND M.J. BECHARD. 1994. Breeding ecology of the Northern Goshawk in high-elevation aspen forests of northern Nevada. Studies in Avian Biology 16:119-121.

Received 12 December 2016; accepted 27 February 2017 Associate Editor: David E. Andersen 